\title{
IMPACT OF COVID19 IN INDIAN STOCK MARKET WITH FOCUS ON BANKING SECTOR
}

\author{
Ms. Avantika Jaiswal ${ }^{1}$, Dr. Ruchi Arora ${ }^{2}$ \\ ${ }^{1}$ Student - MBA Fin, Amity University, Uttar Pradesh \\ ${ }^{2}$ Assistant Professor, Amity University, Uttar Pradesh \\ (E-mail: avantikajaiswal4@gmail.com)
}

(E-mail: raroral@amity.edu)

\begin{abstract}
Covid-19 related lockdowns are forced over and whole country is affected and all the sector. Financial markets have been confronting high unpredictability because of this virus. Monetary foundations have begun experiencing liquidity imperatives. The performance in India of the banking sector is most likely linked to the economy rather than any other sector. The banking sector which is already reeling under a multi decade low credit growth will be hit by fresh asset quality woes as loan collections will be hit as both large and small companies come to terms. The development of the Indian economy is eased to have slowed down significantly. The covid19 have affected the banking sectors' performance in India resulting that the market is going down. Here researcher's objective is to study the impact of covid19 on Indian stock market on banking sector.
\end{abstract}

Keywords - Covid19, Indian Stock Market, Banking Sector, Nifty Bank

\section{INTRODUCTION}

Covid19 is an infectious disease caused by a newly discovered virus named corona virus. This virus is mainly transmitted through droplets generated when an infected person coughs sneezes or exhales. Corona virus is affecting almost every economy in the world very badly. It came as an unprecedented shock that the world led to global health crisis which is having a deep impact on how we perceived our lives till now. In just a period of few months, world has changed. Many of people have already died and hundreds of lakhs surfing from this virus because of this pandemic created by Coronavirus which was previously unknown until it appeared in the city of Wuhan (China) in December 2019 While reading many research paper and article it has communicated that the coronavirus outbreak hits the market and the economy of the country. Also it is noted that the Indian Stock Market has been affected by this coronavirus and there is a fall in the prices of share of companies of every sector. In India banking sector is the backbone of the Economy. So, this study will go into deep analysis of the impact of coronavirus in Indian Stock Market especially on the banking sector that how this virus will affect the Indian Stock Market. We will also try to determine that is the Stock Market enough strong, that it can face the shortcomings in the market due to this pandemic. The Indian stock market has suffered its worst time coronavirus rout in history and the rupee plunged more than $1 \%$, with the investors which stuck in the selling frenzy as the covid19 disrupted businesses and forced the several districts into the lockdown. The markets have become completely chaotic and there is no respite to the sell off mode erasing investor wealth like never before. While reading and observing many recent literature review on coronavirus, it has noticed that any is no research had been done on the impact of covid19 on Indian Stock Market with focus on banking sector. When coronavirus came in India then the market goes down which have a huge loss. Bank Nifty speaks to the 12 generally fluid and huge promoted stocks from the financial division which exchange on the National Stock Exchange (NSE). It provides investors and markeqt intermediaries a benchmark that captures the capital market performance of Indian banking sector.12 banks are as follow which come under nifty bank which are as follow: HDFC Bank, ICICI Bank, Kotak Mahindra Bank, Axis Bank, State Bank of India (SBI), IndusInd Bank, Bandhan Bank, Federal Bank, Bank of Baroda, RBL Bank, IDFC First Bank Ltd., Punjab National Bank (PNB)

HDFC Bank has the most elevated weightage having 29.74\% weightage in Bank Nifty Stock Companies record List, while ICICI Bank stays at second having $19.32 \%$ weightage and Kotak Mahindra Bank on $3^{\text {rd }}$ it has $16 \%$ in Bank Nifty Companies Index List in it. The least weightage in Bank Nifty Index with $0.62 \%$ is PNB. There was avoidance of Yes Bank in the Bank Nifty Index on March 


\section{International Journal of Engineering Technology and Management Sciences[IJETMS]}

Website: ijetms.in Issue:4, Volume No.4, July-2020 DOI: 10.46647/ijetms.2020.v04i04.008

19, 2020. Bandhan Bank has been remembered for Bank Nifty Index. The banking sector which is already reeling under a multi decade low credit growth will be hit by fresh asset quality woes as loan collections will be hit as both large and small companies come to terms with the 21-day lockdown to prevent the spread of the coronavirus. The rating agency by the expects forecasted the credit growth to remain slow at below $6 \%$ amid muted economic activity in the financial year of 2021. Slow credit growth will add to profitability pressures for banks amid likely increase in credit provisions as asset quality stress likely to go up. . Every country is going through an economic slowdown due to this pandemic. It has also adversely affected the banking sector of our country. The banks in the country are working at reduced capacities, providing only essential services. Only essential banking services like deposits, withdrawals, clearing of cheques, etc. are provided to the general public.

\section{2- About Nifty Banks}

Under nifty bank there are 12 banks which are as follow:

\section{1-HDFC BANK}

The Housing Development Finance Corporation Limited (HDFC) bank was founded on August 1994 before 25 year, its headquarter is in Mumbai and it the India's largest private sector bank. HDFC Bank is private sector bank giving a wide scope of banking administrations covering business and venture counts on the discount side and valuebased/branch relying upon the retail side. It has the merger with Times Bank in February 2000. In 2019 this bank has awarded as a best private sector bank and many smore.

. The Bank is all around situated as a pioneer in different net based B2C openings including a wide scope of web banking administrations for Fixed Deposits, Loans, Bill Payments, and so forth.

\section{2-SBI}

State Bank of India (SBI) was founded on 1 July 1995 and its headquarter is in Mumbai. It was the first bank which was established in India as Bank of Calcutta in 1806. The chairman of SBI is Rajnish Kumar. It has 16 regional hubs and 57 zone offices that are located in India and over 24000 branches in India, and it also operate several subsidiaries. It provides many services such as Investment, Loan, Saving, Deposit account, cards, banking and many more. It offers a scope of general financial administrations from advances and advances to corporate and people in India and abroad. Since it is state-claimed, SBI is the favoured financier for most open division organizations. SBI, alongside its partner banks, offers smaller scale financing to elements, for example, self improvement gatherings in country territories that would somehow or another have no entrance to formal credit channels It is public sector bank.

\section{3-Axis Bank}

Axis Bank was established in 1993 and started in 1994 and it is third largest private sector bank in India. Axis bank have 3,304 branches, 14,163 ATMs 9 international offices. According to Axis Bank's annual report for the financial year 2016-17, it has 202 lakhs savings bank account customers, The Bank was started it with a capital of Rs. 115 crore, with UTI contributing Rs. 100 crore, LIC for Rs. 7.5 crore and GIC and its four subsidiaries contributing Rs. 1.5 crore each. The Bank has qualities in both retail and corporate banking and is focused on embracing the best business rehearses globally so as to accomplish greatness. Services offered by this bank are as follow:

- Personal Banking

- Corporate Banking

- $\quad$ NRI Banking

- $\quad$ Priority Banking

\section{4--ICICI BANK}

Industrial Credit and Investment Corporation of India (ICICI) was established in 1994.It is public sector bank. It is India's second largest bank. ICICI BANK was founded as the Industrial Credit and Investment Corporation of India Bank, before changed its name to the abbreviated ICICI Bank. In 2003 ICICI bank set up its first branch in Singapore and in 2004 Bangladesh and South Africa. This bank is mainly engaged with economic and human development at the national level.

\section{5- Kotak Mahindra bank}

Kotak Mahindra bank is a private sector bank and founded in February 2003 by Uday Kotak and its headquarter is in Mumbai, Maharashtra. It provides financial services for both corporate as well as retail customer. The key business of this bank is doing commercial banking, investment, stock broking, vehicle finance, advisory services, assets management, and serval insurances. This bank also offers complete financial solutions of all type of need to the individual and non individual customers depending on the 


\section{International Journal of Engineering Technology and Management Sciences[IJETMSS]}

Website: ijetms.in Issue:4, Volume No.4, July-2020 DOI: 10.46647/ijetms.2020.v04i04.008

customers need. It also offer investment services like mutual fund, insurance, gold coins etc. Apart from phone banking and internet banking it also provide convenient banking facilities through mobile banking services, SMS etc. It is the fasted growing bank in the Indian financial institutions.

\section{6- PNB}

Punjab National Bank (PNB) was established in 1894 and its headquarter is in New Delhi and it public sector bank. It is the largest second public sector bank in India. The main purpose of PNB bank was business banks in India. They offer financial items, and furthermore work MasterCard's and check card business, bullion business, life and non-life coverage business, and gold coins and resource the board business. They are perceived as the bank offering most elevated levels of consumer loyalty in Delhi and Chennai.

\section{7-Bandhan bank}

Bandhan bank was established on 23 August 2015 and its headquarter is in Kolkata, West Bengal. At this time Bandhan bank has 4559 banks outlay in India. In 2018 it became the $8^{\text {th }}$ largest bank in India. A Bandhan Bank investment account gives a large group of banking benefits like adaptable simple records the board, alongside a serious financing cost. You can make fast service charge instalments by means of Net Banking, and appreciate different highlights in accommodation keeping money with a Bandhan Bank Savings Account.

\section{8-RBL}

Ratnakar Bank Limited (RBL) scheduled commercial bank headquartered in the Kolhapur Maharashtra, India. It is established on August 1943, one of the oldest private bank in India. RBL Bank is one of India's quickest developing private sector bank which keeps money with a growing nearness the nation over. RBL offers particular administrations under the six business verticals to be specific is in Corporate and Institutional Banking, Commercial Banking, Branch and Business Banking, Retail Assets, Development Banking and Financial Inclusion, Treasury and Financial Markets Operation. It at present administrations over 8.49 million clients through a system 1,631 Offices (386 Branches and 1,245 BC Branches) spread across 28 Indian States and Union Territories.ith a Bandhan Bank Savings Account.

\section{9-Bank of Baroda}

Bank of Baroda was founded on 20 July 1809, and its headquarter is in Vadodara, Gujarat, India. Bank of Baroda is one of the main business banks in India. The Bank's answers incorporates individual financial which incorporates stores gen-next administrations retail advances MasterCard's platinum cards administrations and storage spaces; business banking which incorporates stores advances and advances administrations and storage spaces; corporate financial which incorporates discount banking stores advances and advances and administrations and worldwide business which incorporates non-inhabitant Indian (NRI) administrations remote cash credits ECB seaward financial fare money import account reporter banking exchange fund and global treasury. The Bank offers administrations, for example, local tasks and For-ex activities. They additionally offer provincial financial administrations which incorporate stores need segment propels settlement assortment administrations annuity and storage space

\section{0-IDFC}

IDFC bank was established on 1 October 2015 and listed in NSE AND BSE on 6 November 2015. Its headquarter is in Mumbai, Maharashtra. IDFC FIRST Bank gives a scope of money related answers for the people, independent ventures and corporate. The Bank offers investment funds and current records, NRI accounts, pay accounts, fixed and repeating stores, home and individual advances, independent venture advances, instalment arrangements and riches the board administrations. IDFC FIRST Bank has an across the country nearness and works in the Retail Banking, Wholesale Banking and other financial sections. Clients can pick where and how they need to bank: 260 branches, 140 ATMs and 454 provincial business journalist focuses the nation over, net banking, portable banking and all day, every day cost free Banker-on-Call administration.

\section{1-IndusInd Bank}

IndusInd bank was established on 1994 and its headquarter is in Pune Maharashtra. IndusInd Bank is the first among the new-age private banks in India. The bank offers business, value-based and electronic financial items and administrations. The bank has represented considerable authority in retail banking administrations and ceaselessly 


\section{International Journal of Engineering Technology and Management Sciences[IJETMS]}

Website: ijetms.in Issue:4, Volume No.4, July-2020 DOI: 10.46647/ijetms.2020.v04i04.008

overhauls its emotionally supportive networks by presenting more up to date advances.

\section{2- Federal Bank}

Federal bank was established on 2 December 1949 and its headquarter is in Kochi, Kerala and it private sector bank. The Bank is a pioneer among customary banks in India in the region of utilizing innovation to use its tasks and was among the first banks in a while to modernize every one of its branches. The Bank offer its clients, an assortment of administrations, for example, Internet banking, Mobile banking, on-line charge instalment, online expense assortment, storehouse administrations, Cash Management Services, shipper banking administrations, protection, shared reserve items and a lot more as a feature of its technique to situate itself as a money related grocery store and to upgrade client accommodation.

\section{LITERATURE REVIEW}

In this (1) Aravind M \& Manojkrishnan C G. (2020) made their research paper on. COVID 19: Effect on the leading pharmaceutical stocks listed with NSE. International Journal of Research in Pharmaceutical Sciences.Covid19 outbreak has affected leading pharmaceutical stocks listed with the National Stock Exchange of India and the stock are maintaining their momentum with the market index of Nifty. And the demand of pharmaceutical stock should increase in the coming days (2) Singh, Jaspreet and Singh, Jagandeep (2020) published their research paper on the topic COVID-19 and Its Impact on Society. Elect0ronic Research Journal of Social Sciences and Humanities, Vol 2: Issue I, 2020 in which they mention about the impact on the society which include all the sector of the country as well as the people facing health issue which increase the death morality rate in country. Society is facing many problems. (3) Sunil Kumar, Pratibha B Thombare and Pandurang A Kale (2020) published their research paper on Impact of Covid19 on Indian Economy in which they mentioned about the impact of corona virus in the Indian Economy that India is estimated to be about 348 million dollars and the country figures among the top 15 economies most affected as slowdown of manufacturing in China disrupts world trade, according to a UN report. Whereas according to Asian Development Bank (ADB) the Covid19 outbreak could cost the Indian economy between \$387 million and \$29.9 billion in personal consumption losses. (4) Richard Baldwin and Beatrice Weder di Mauro (2020) published their research paper on Economics in the Time of COVID-19, CEPR Press A. In this they mentioned about the decreasing in the GDP rate of the country. There is collapse of stock market all over the country. And in there is fall in the GDP rate and REPO rate which cause a huge loss for the country. If the REPO rate will decrease than it cause deflation.

(5)Patil Anoop. Narayan Parab, and Y. V. Reddy, (2018) published their research paper on Analyzing the Impact of Demonetization on the Indian Stock Market: Sectoral Evidence using GARCH Model in their research paper they mentioned about the effect of demonetization on Nifty 50 Index and across sectoral lists in India considering a time of 200 days earlier and post occasion date by encircling important sham factors. The investigation saw the information as fixed utilizing the Augmented Dickey-Fuller Test. A noteworthy exchange returns was prove from Nifty 50 Index and sectoral records, for example, Nifty Auto Index, Nifty Financial Services Index, Nifty FMCG Index, Nifty IT Index, Nifty Media Index, Nifty Private Bank Index, and Nifty Realty Index.(NSE) and the Calcutta Stock Exchange (CSE). These three are biggest Indian Stock Market. Unpredictability is a factual proportion of the scattering of profits for a given security or Market Index (6) Varsha Kachroo (2020) published her research paper on Novel Coronavirus (Covid19) in India: Current Scenario in this she mentioned about the coronavirus that how India will learn from China, Italy and other countries which are affected by coronavirus. In India many things are done related to coronavirus. She also mention about the quarantine and lockdown. She also mention about those who travel from China, Italy, Iran, German they all are kept in the quarantine for the 14 days. (7) Dr.S.Gayathri and Mangai T (2018) published their research paper on A Critical Analysis of the Punjab National Bank Scam and its Implications they mentioned about PNB Rs 12,700 crore trick includes in any event six banks, raising questions over the inner security of tasks in monetary firms. It might be noticed that the PSBs lost in any event Rs 227 billion to bank fakes over the most recent five years. The greatness of PNB trick is extravagant and it has been going on for over five years undetected. This offers genuine conversation starters into the interior tasks and evaluating forms. The summit bank of the nation RBI is confronting open rage for not having the option to recognize the biggest financial trick. This research paper plans to recognize and break 


\section{International Journal of Engineering Technology and Management Sciences[IJETMSS]}

Website: ijetms.in Issue:4, Volume No.4, July-2020 DOI: 10.46647/ijetms.2020.v04i04.008

down the components that prompted this enormous trick.(8) Mannu Goyal, Devansh and Alpana Bansal published research paper on A Deep Study of Various Frauds Happening in Indian Banks and Commendations to Overcome Frauds in which they mentioned about the Banking is the foundation of the economy and aides in money related development however India is as yet confronting the various frauds where NPA's are increasing year over year basis and significant cheats occurring by top management. These fakes lead to Economic Slowdown. As indicated by the study Employees of banks, Poor Governance of Public part Banks and Recapitalization lead to misrepresentation. Numerous issues are going in the financial framework like absence of legitimate credit checking, absence of appropriate dispensing of advances. The strategy for pre-authorizing and post-endorsing of credits is likewise to be given due determination to have power over the NPA. (9) Kaushik Dora Hanumantu, Vidula Worlikar and1 Sundaravalli Narayanaswami (2019) published a research paper on The Punjab National Bank scam: Ethics versus robust processes in which they mentioned about the rising occurrences of corporate tricks, it has gotten basic to lift the corporate cover to uncover the explanations for them. Accordingly, it is of foremost significance to analyze the development of the organizations going into the agreement-the officials, executives, and top administration. A large-scale trick hit the Punjab National Bank (PNB) in India as of late with enormous ramifications on its monetary position and validity. It is deduced through this work infringement of governing rules prompted the immense trick. (10)Thomas Kurien, Ramesh Bhat, Arni S. R. Srinivasa Rao, and Sudhakar Kurapati (2020) published their research paper on Addressing Immediate Challenges in Controlling COVID19 in India in that they mention about The Government of India (GOI) has taken many proactive steps to control the epidemic, including the total lockdown of the nation to flatten the epidemic curve and reduce the case fatality rate. India has chosen a strategy of large-scale quarantine and limited testing and not extensive testing and limited quarantine. This is because we have a large population of 1.3 billion, and many states in India have the comparatively limited testing capacity to deal with a large-scale epidemic. The timeline that we get by flattening the curve should be urgently utilized to plan and implement interventions that help preventing further spread of the disease. (11) Dhanraj Sharma, Ruchita Verma and Shiney Sam (2019) published their research paper on Impact of Fraud Announcement on the Stock Price: Analysis of Indian Banks in which they mentioned about the fraud declaration is an unscheduled occasion in the capital market that is probably going to impact budgetary execution of the concerned firm. The banking sector is well regulated, yet it suffers from diverse obstacles such as financial distress and lack of ethical practices. The fraud had been increasing in banks which further lead to antagonistic ramifications for the economy. The contemplates that underscored on the data impact of cheats on stock cost are infrequently found with regards to Indian banking segment. In this examination, we research the response of stock costs to the arrival of data with respect to misrepresentation in banks. (12)Uma Priyadharshini. S and Dr. S. A. Lourthuraj (2019) published research paper on Impact of Demonetization on performance of select banks listed in NSE - an empirical study in which they mentioned about the effect of demonetization on the exhibition of chose Banking Sector organizations recorded in National Stock Exchange. The financial segment is chosen for the examination since it is said to be effective and rapidly acclimate to all freely accessible new data in a fair-minded style. The major destinations of this investigation is to test the effect of demonetization on the presentation of chose Banking Sector organizations, to assess the danger of the stocks specifically record and to offer important proposals to the financial specialists to take the correct venture choice. An occasion study was directed and the declaration of demonetization was taken as the occasion. The motivation behind the examination was to see if the demonetization has affected the exhibition of the chose banks emphatically or adversely. (13) Saurabh Krishna and Dr Razit Sharma published a research paper on Bank Frauds: Emerging Challenges in India in which they mention about the banking sector is again in the limelight, especially as we stand today on the brink of the fourth industrial revolution. The banking system plays an important role in promotion of economic growth not only by channelling savings into investments but also by improving the allocation of financial resources into the stressed-out sectors of the industries. An efficient banking system is now considered as a necessary pre condition for the growth of a country in a stable manner. In any case, this has not come without its due part of traps.(14)Deepanshu Mohan (2020) published research paper on What Will Be the Economic Consequences of COVID-19 for India and the World in this 


\section{International Journal of Engineering Technology and Management Sciences[IJETMS]}

Website: ijetms.in Issue:4, Volume No.4, July-2020 DOI: 10.46647/ijetms.2020.v04i04.008

he mentioned about banking area is again in the spotlight, particularly as we stand today near the very edge of the fourth modern unrest. The financial framework assumes a significant job in advancement of monetary development not just by diverting reserve funds into ventures yet additionally by improving the portion of monetary assets into the worried segments of the businesses. An effective financial framework is currently considered as an essential pre condition for the development of a nation in a steady way. In any case, this has not come without its due piece of traps (15) Dr. J.T. Pratheeesh and Dr. G. Arumugasamy (2020) published research paper on Impact of covid19 in Indian Economy and Banking Sector in which they mentioned about an effort made to know the real face of the economy and banking sector in India during the massive spread of covid-19. In their study they have covered the areas such as the impact of corona virus towards the Indian economy and Overseas. Also the study has explored the Sector-wise impact on Indian industry, where the readers can get a good idea about the existing position of the industries such as chemical Industry, shipping industry, Auto industry, Pharmaceuticals industry, Textiles industry, Solar power sector, Electronics industry, IT industry, Tourism and aviation.

\section{RESEARCH METHODOLOGY}

\section{III.1-OBJECTIVES}

1-To deeply understand covid19 and its impact on Indian stock market in banking sector

2-To understand the current scenario of Indian stock market of banking sector

3-Comparative analysis of the deviations occurred in the stock prices of nifty banks pre and during covid 19

\section{III.2 RATIONALE}

Covid19 affected almost everything globally. But the rationale behind choosing the Indian stock market on focusing banking sector that what is the impact of covid19 on Nifty banks and what things are to be done to improve the condition of the banks. In India lockdown is going so the market is not working and the banks are going worst condition ever during this pandemic.
Through this research paper one can become more acquainted with how this division is being drained in the hour of this pandemic and how this virus Covid-19 resets the clock and time on 5 years in length nifty bank blast that has been ,no doubt, one of the pandemic happened all over the world.

\section{III.3-RESEARCH GAP}

1-Till date no research paper has been made on impact of covid19 on Indian stock market in banking sector: Since covid19 is a pandemic that the world is going through these days, so no research paper has been made on the impact of covid19 on Indian stock market in banking sector.

2-The time of study has not been defined in other related research paper: In other research paper the time has not been defined that which time period is to be taken.

3-Data related to this topic will be from current scenario : The data which we will take for the research paper will be of current scenario and being updated by day to day which is a drawback and research gap because the data which an author take for the research paper today might become outdated tomorrow.

\section{III.4 -RESEARCH METHODOLOGY}

This research study has been done by the secondary source of data, the secondary source which will be collected from the Indian share market of banking sector available on the websites of nseindia.com, bseindia.com, money control etc., and some articles and journal related to this topic. Descriptive research design using quantitative technique will be done Descriptive research also describes the characteristics of relevant sector. The sole instrument for data collection is the data of the share prices of nifty banks available on the website of stock exchanges and the passenger volumes of these companies posted on their website. Also calculate the standard deviation in $\mathrm{ms}$ excel. And tables and Charts are have been made for the Analysis and Interpretation purpose.

\section{III.5 TOOLS USED}




\section{International Journal of Engineering Technology and Management Sciences[IJETMS]}

Website: ijetms.in Issue:4, Volume No.4, July-2020 DOI: 10.46647/ijetms.2020.v04i04.008

\section{Standard Deviation}

Standard Deviation is a statistical tool that expresses how much the members of any group differs from the mean value of that group. It tells us how measurements of a group are spread out from the mean value. The lower the Standard Deviation is, the better it is. A lower Standard Deviation depicts that majority of the numbers are close to the average and a higher Standard Deviation depicts the majority of the numbers are far away from the average value.

\section{Formula}

$\sigma=\sqrt{\frac{\sum \mathrm{i}=1(\mathrm{xi}-\mathrm{x}) 2}{n-1}}$

\section{Earnings per Share}

EPS are the earnings in monetary terms per outstanding share of common stock of a company. It is also a measure to show how much profit a company has earned in a particular period of time. In general companies report their EPS on quarterly, half - yearly or yearly basis in their own accounts statements. It is that portion of the profit of a company that has been allocated to each outstanding share of its own common stock. Calculating EPS considers the growth and stability of a company's earnings for past 3 years concerning more on last 3 quarters. The results are assigned on a scale of $1-99$. The higher the EPS, the better financial condition a company has.

\section{Non - Performing Assets}

In India, the Central Bank Reserve Bank of India is the head of all commercial as well as non - commercial banks in India. RBI monitors the whole banking system of the country. As per the statement of RBI, a loan account can be termed as a Non - Performing Asset, if its interest of instalment amount is overdue for a period of 90 days or more. The NPAs should be as much lowest as possible. An NPA implies that a bank can neither credit an income nor debit any losses, unless recovered or identified as loss. The increased NPA puts pressure on the recycling of funds and lowers the ability of a bank for lending more money.

\section{Comparative Analysis}

Comparative Analysis is used to decide and evaluate connections between at least two factors by watching various gatherings that either by decision or circumstances that are exposed to different treatment. Comparative Analysis considers at least two comparative gatherings, people, or conditions by comparing them. A company's comparative analysis against other companies in their industry evaluates the results and overall performance of the company. The main of the comparative analysis is to identify the similarities and differences between different companies.

\section{ANALYSIS AND INTERPERATION. DATA ANALYSIS}

Data which are used in this research paper is collected from the website nseindia.m, mcom, bseindia.com, etc. From $1^{\text {st }}$ April 2019 to 31 March 2020, Nifty banks included 12 banks which are as follow HDFC Bank, ICICI Bank, Kotak Mahindra Bank, Axis Bank, State Bank of India (SBI), IndusInd Bank, Bandhan Bank, Federal Bank, Bank of Baroda, RBL Bank, IDFC First Bank Ltd., and Punjab National Bank (PNB).

1-STANDARD DEVIATIONS OF ALL THE NIFTY BANK AS: PRE AND DURING COVID19

\begin{tabular}{l|r|r|}
\hline & PRE COVID19 PERIOD & DURING COVID19 PERIOD \\
BANKS & SANDARD DIVIATION & STANDARD DEVIATION \\
\hline HDFC & 0.170596092 & 0.630610488 \\
\hline SBI & 0.387765 & 0.616477 \\
\hline AXIS & 0.245687139 & 0.738081128 \\
\hline BANDHAN BA & 0.543261 & 1.239237 \\
\hline FEDERAL & 0.28663 & 0.752801 \\
\hline IDFC & 0.31783 & 0.705381 \\
\hline INDUSIND & 0.382974 & 1.254273 \\
\hline KOTAK MAHII & 0.182561 & 0.579047 \\
\hline PNB & 0.363434 & 0.516962 \\
\hline RBL & 0.658811 & 0.891951 \\
\hline ICIC & 0.245097 & 0.601116 \\
\hline BANK OF BAR & 0.387765 & 0.616477 \\
\hline
\end{tabular}

I had taken the data of all the 12 banks of nifty and divide the data into two parts that is from 1october 2019 to 31 December 2019 that is pre covid19 situation in which there was not any covid19 things and the other data that is from 1January 2020 to 31 March 2020 is was during covid19 period. I had calculated the standard deviation from the SQUT of the annualised risk of both the data. If we look to the data we find that the value of standard deviation of all 


\section{International Journal of Engineering Technology and Management Sciences[IJETMSS]}

Website: ijetms.in Issue:4, Volume No.4, July-2020 DOI: 10.46647/ijetms.2020.v04i04.008

data of pre covid19 was low causing stable return and during covid19 value of standard deviation of all the bank are more due to economic slowdown the returns declined rapidly causing a major deviation or fluctuation.

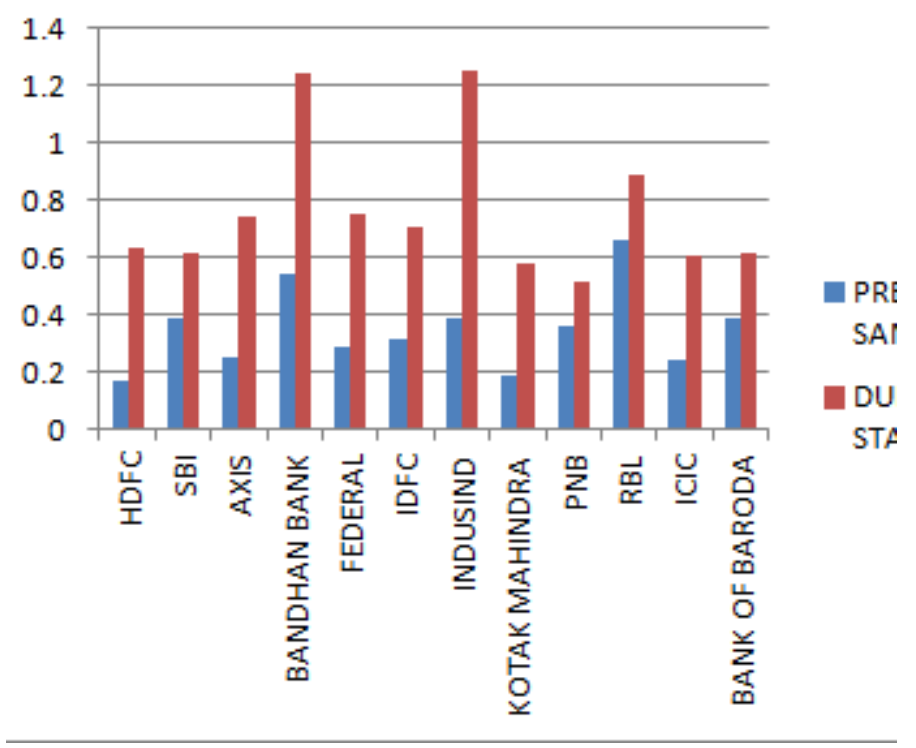

Chart-1

From the above chart that in the covid19 period there was more standard deviation as compared to pre covid19 as we can see Bandhan bank and IndusInd bank have highest standard deviation in covid19 period and PNB and Kotak Mahindra bank have less standard deviation as compared to others.

\section{2-FORECAST OF EPS OF 4 BANKS:}

\begin{tabular}{l|r|r|r|r|r|} 
YEAR & $\mathbf{2 0 1 5}$ & $\mathbf{2 0 1 6}$ & $\mathbf{2 0 1 7}$ & $\mathbf{2 0 1 8}$ & $\mathbf{2 0 1 9}$ \\
\cline { 2 - 7 } $\begin{array}{l}\text { HDFC-EPS } \\
\text { AXIS bank-EPS }\end{array}$ & $\mathbf{4 9}$ & 57 & 68 & $\mathbf{7 9}$ & $\mathbf{4 8}$ \\
\cline { 2 - 7 } & 34.59 & 15.4 & 1.13 & 18.2 & 5.99 \\
\cline { 2 - 7 } & & & & & \\
\cline { 2 - 7 } SBI-EPS & 15.95 & 0.31 & -5.34 & 2.6 & -5.0 \\
\cline { 2 - 6 } PNB-EPS & -20.82 & 6.45 & -55.39 & -30.94 & -55.2385
\end{tabular}

Table-2

From the above chart we had calculated the forecasted value of four bank that is HDFC, AXIS, SBI and PNB bank we had calculated or forecasted the future value in excel sheet by using the formula we were having the EPS of these bank from 2015-2019 and we had forecasted the EPS from 2020-2024.

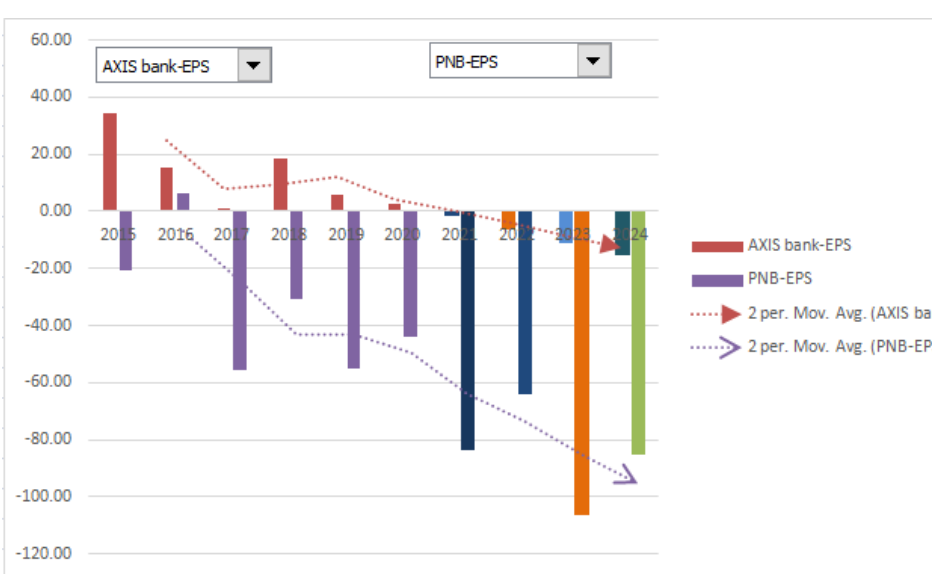

\section{Chart-2}

The above chart show the data forecasting of EPS in Axis and PNB bank that the value of EPS started decreasing in the upcoming year

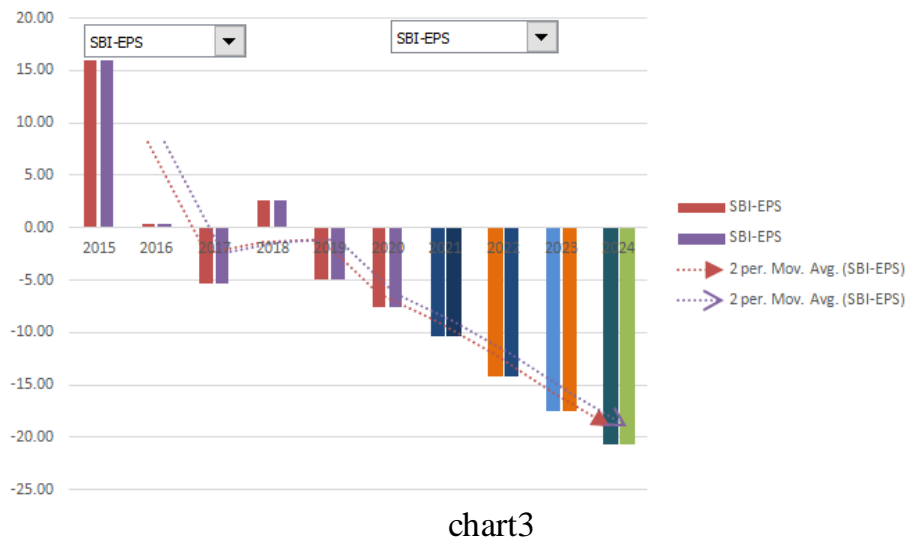

The above chart show the decline in EPS value of SBI in the upcoming year that value goes into negative.

\section{3-FORECAST OF NPA}




\section{International Journal of Engineering Technology and Management Sciences[IJETMSS]}

Website: ijetms.in Issue:4, Volume No.4, July-2020 DOI: 10.46647/ijetms.2020.v04i04.008

\begin{tabular}{l|r|r|r|r|r} 
& $\mathbf{2 0 1 5}$ & $\mathbf{2 0 1 6}$ & $\mathbf{2 0 1 7}$ & $\mathbf{2 0 1 8}$ & $\mathbf{2}$ \\
\cline { 2 - 6 } $\begin{array}{l}\text { YEAR } \\
\text { HDFC-NPA }\end{array}$ AXIS bank-NPA & 1320.37 & 1843.99 & 2601.02 & 3214.52 & 354 \\
\cline { 2 - 6 } & 2522.14 & 8626.55 & 16591.71 & 11275.6 & 936 \\
\cline { 2 - 6 } & & & & & \\
\cline { 2 - 6 } & 55807.02 & 58277.38 & 110854.7 & 65894.7 & 934 \\
\cline { 2 - 6 } SBI-NPA & 35422.6 & 32702.1 & 48684.3 & 30037.7 & 3661 \\
\hline
\end{tabular}

table-3

The above table shows the NPA of four bank that are HDFC, AXIS, SBI AND PNB in this we had forecasted the value of NPA in these banks in ms-excel and we find than in the upcoming year from 2020 to 2024 the NPA will increase of all the taken banks.

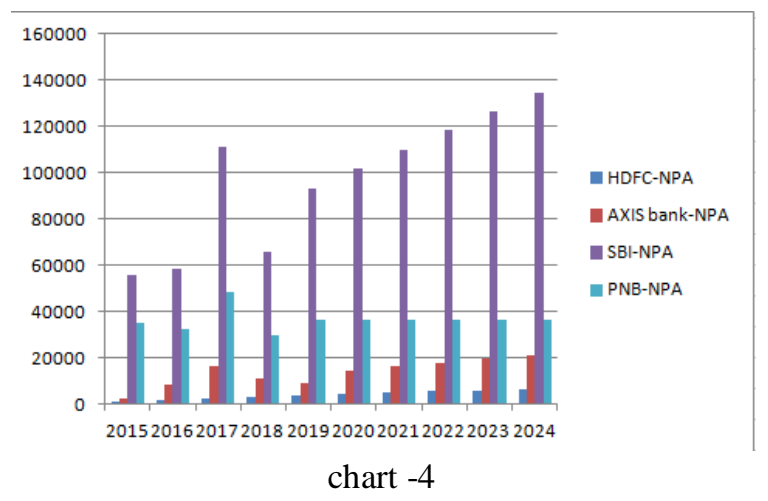

\section{4- COMPARATIVE ANALYSIS OF EPS AND NPA OF ALL THE BANKS}

EPS OF ALI

\begin{tabular}{|c|c|c|c|c|c|c|}
\hline YEAR & HDFC & SBI & KIS BAK & ANDHAN BAN & FEDERAL BANK & IDFC \\
\hline $2015-16$ & 48.84 & 15.95 & 34.59 & 3.4 & 2.77 & 2.3 \\
\hline $2016-17$ & 57.18 & 0.31 & 15.4 & 10.15 & 4.83 & \\
\hline $2017-18$ & 67.76 & -5.34 & 1.13 & 12.26 & 4.62 & 2.5 \\
\hline $2018-19$ & 78.65 & 2.58 & 18.2 & 16.36 & 6.28 & -0.4 \\
\hline $2019-20$ & 48 & & 5.99 & 18.78 & & \\
\hline
\end{tabular}

Table 4 shows the Eps of the 12 Nifty banks for a period of 5 years. For the year 2015-16, HDFC Bank has the highest EPS, i.e., 48.84 and BOB has the Lowest EPS being -23.89. For the year 2016-17, HDFC Bank has the highest EPS, i.e., 57.18 and SBI has the Lowest EPS being 0.31. For the year 2017-18, HDFC Bank has the highest EPS, i.e., 67.76 and PNB has the Lowest EPS being -55.39. For the year 2018-
19, HDFC Bank has the highest EPS, i.e., 78.65 and PNB has the Lowest EPS being -30.94. For the year 2019-20, INDUSIND Bank has the highest EPS, i.e., 63.75. On the basis of above comparative analysis, here we can conclude that HDFC Bank and INDUSIND bank are more stable and are earning more profits as compared to other banks and PNB having the lowest EPS depicts its losses for consecutive years.

NPA

\begin{tabular}{|c|c|c|c|c|c|c|c|c|c|c|c|c|}
\hline \multicolumn{13}{|c|}{ NPA OFBAllKS } \\
\hline & & & & BANDHAII & & & & KOTHK & & & & of \\
\hline YEAR & HOFC & SBI & BAHK & BAKK & FEDERALL BANK & IDFC & |NDUSIND & MAHNDRA & PNB & RBL & |CICI & BAFOD \\
\hline $2015-16$ & 1820.4 & 550070.02 & 25221 & & 950.01 & 1939.4 & 33175 & 186196 & 3542.2 & 124.4 & 13268 & 8 (1940.5.5. \\
\hline $2016-11$ & (1844| & 58277.38 & 862666 & & 944.2 & 576.47 & 48999 & $1780.00 \mid$ & 320 & 1899.9 & 2545 & 118800.2 \\
\hline $2017-18$ & 2000 & 102554.7 & 16552 & 1729 & 155169 & 89111. & 755.67 & 1665.055 & 486824 & 3125 & 27866 & 323427 \\
\hline $2018-19$ & 327.5 & 659947.74 & 1126 & 228.32 & 1226.2 & 1066.6 & 2246.28 & 1544.31 & 3003 & 3727 & 1357. & $\begin{array}{l}4 \\
4\end{array}$ \\
\hline $2019-2$ & (3) 3924 & & 93904 & 3094.4 & & & 1806556 & & & 1869.3 & 10132 & \\
\hline
\end{tabular}

Table 5

Table 5 shows the NPA of all the 12 banks taken into consideration for this study for a period of 5 years. For the year 2015-16, RBL has the lowest NPA, i.e., 124.44 and SBI has the highest NPA, i.e., 55807.02. For the year 2016-17, RBL has the lowest NPA, i.e., 189.94 and SBI has the highest NPA, i.e., 58277.36. For the year 2017-18, RBL has the lowest NPA, i.e., 132.56 and SBI has the highest NPA, i.e., 110854.7. For the year 2018-19, Bandhan Bank has the lowest NPA, i.e., 228.32 and SBI has the highest NPA, i.e., 65894.74. For the year 2019-20, Bandhan Bank has the lowest NPA, i.e., 389.4. So, on the basis of above comparative analysis of NPA, we can conclude that RBL and Bnadhan Bank have the lowest NPA, that means they have less recycling of funds and higher lending ability

\section{5-CURRENT INFORMATION ABOUT BANKING INDUSTRY DURING COVID19 SITUATIONS}

1. COVID - 19 has hit every economy very hard new loans, project appraisals, reworking existing work loans do not fall under the 


\section{International Journal of Engineering Technology and Management Sciences[IJETMSS]}

Website: ijetms.in Issue:4, Volume No.4, July-2020 DOI: 10.46647/ijetms.2020.v04i04.008

category of essential services being provided by the banks during this pandemic situation.

2. Due to this economic slowdown, banks are likely to witness a spike of $1.9 \%$ in their non - performing assets and of 130 basis points in credit cost ratios. Banks have faced a second - order hit as c compared to the corporate and household sector.

3. Central bank and supervisory authorities have rolled out diverse measures to address COVID - 19. RBI in its seventh bi - monthly monetary policy announced the reduction in the repo rate by 75 basis points to $4.4 \%$.

4. It will also provide liquidity to banks through reduction in the CRR and by increasing the limit for Marginal Standing Facility.

5. RBI has also allowed a repayment moratorium for 3 months to the borrowers of all commercial banks and Non - Banking Financial Institutions including housing finance companies and micro - finance institutions.

6. HDFC Bank has the most elevated weightage having $29.74 \%$ weightage in Bank Nifty Stock Companies record List, while ICICI Bank stays at second having $19.32 \%$ weightage and Kotak Mahindra Bank on $3^{\text {rd }}$ it has $16 \%$ in Bank Nifty Companies Index List in it. The least weightage in Bank Nifty Index with $0.62 \%$ is PNB. There was avoidance of Yes Bank in the Bank Nifty Index on March 19, 2020.

7. The banks are moving to the era of digitalization in their working system and enabling customers to deal online being at home. When this COVID -19 situation is past us, it is expected that the Indian Banks will shift gears to move away from the traditional ways of banking and move towards digitalization. This pandemic situation will not only accelerate the adoption of technology, but will renew focus on four key areas of banking:

- Embracing neo technologies

- Channels of digitalization

- Security, privacy and customer trust

- Policy and compliance

\section{FINDINGS}

On the basis of analysis the data analysed, the researcher found the following:

1. In first test we have found that in the pre covid19 period the risk of all the bank are near to average mean and stable but during covid19 period the standard deviation was high in all the banks and in the month of March there was a higher record of standard deviation due to lockdown amidst covid19

2. We have find from comparative analysis of EPS of all nifty bank that HDFC and INDUSIND BANK are more stable and earning more profits, whereas PNB is on the lowest edges.

3. We can conclude from comparative analysis of NPA of all nifty bank that RBL and Bandhan Bank have the lowest NPA.

\section{CONCLUSION}

- The covid19 pandemic have affected the banking sectors performance in India resulting that the market is going down

- HDFC and INDUSIND BANK are more stable and earning more profits, whereas PNB is on the lowest edges

\section{LIMITATIONS}

- The study was conducted for a period of 3 months only under covid - 19 situation. The time period taken should be the entire span of this pandemic activity.

- The study was conducted only for the impacts of covid -19 on the banking sector and did not consider other important sectors of the economy.

- The study has taken only the data for 12 nifty banks, so the result may not be completely reliable.

- Only secondary data sources were used in this study and no primary sources have been used.

VII. REFRENCES

1. Aravind M \& Manojkrishnan C G. 2020, COVID 19: Effect on the leading pharmaceutical stocks listed with 
Website: ijetms.in Issue:4, Volume No.4, July-2020 DOI: 10.46647/ijetms.2020.v04i04.008

NSE. International Journal of Research in Pharmaceutical Sciences.

2. Singh, Jaspreet and Singh, Jagandeep 2020, COVID-19 and Its Impact on Society. Electronic Research Journal of Social Sciences and Humanities, Vol 2: Issue I, 2020

3. Sunil Kumar, Pratibha B Thombare and Pandurang A Kale 2020, Impact of Covid19 on Indian

4. Richard Baldwin and Beatrice Weder di Mauro 2020, Economics in the Time of COVID-19, CEPR Press A

5. Varsha Kachroo 2020, Novel Coronavirus (Covid19) in India: Current Scenario

6. Deepanshu Mohan 2020, What Will Be the Economic Consequences of COVID-19 for India and the world

7. Dr. J.T. Pratheeesh and Dr. G. Arumugasamy 2020, Impact of covid19 in Indian Economy and Banking Sector Journal https://www.moneycontrol.com/ stocks/company info/print main.php 